\title{
Land Registration, Governance, and Development: Evidence and Implications for Policy
}

Klaus Deininger and Gershon Feder

The developmental impact of institutions to establish and maintain secure property rights to land has been a subject of much debate. The authors review the literature on the impact of land administration interventions in specific contexts, highlighting the dependence of outcomes on the governance environment, the effectiveness of the state apparatus, and the distribution of socio-economic power. There is evidence, albeit not uniform, of enhancement of tenure security through land registration with benefits manifesting themselves in higher levels of investment and productivity and a reduced need to defend land rights. Land registration has also been shown to increase activity in land rental markets, leading to higher efficiency overall. Evidence of improved access to credit, due to formalization of land rights, is scant. Even in situations where land registration had positive benefits, the literature contains little rigorous analysis of cost-effectiveness and long-term sustainability of impacts. The authors conclude that formalization of land rights should not be viewed as a panacea and that interventions should be decided only after a careful diagnosis of the policy, social, and governance environment. If intervention is justified, the performance of land administration systems needs to be benchmarked in terms of coverage, cost-effectiveness, and quality of service provision. JEL codes: O10, Q15, P14

Development economists have long highlighted the central role of institutions for economic growth and the distribution of its gains among the population (North 1971; Greif 1993). The impacts of different institutional structures related to land rights and their interactions with the distribution of power, as well as overall productivity in society, have been discussed extensively in the literature (Binswanger, Deininger, and Feder 1995; Conning and Robinson 2007). A key reason for the

(C) The Author 2009. Published by Oxford University Press on behalf of the International Bank for Reconstruction and Development / THE WORLD BANK. All rights reserved. For permissions, please e-mail: journals.permissions@oxfordjournals.org doi;10.1093/wbro/lkp007 Advance Access publication June 11, 2009 
continued focus on property rights to land is the fact that in most economies land and real estate are a key part of households' and firms' wealth. The extent to which such assets are used as collateral to access credit that can be used for investment and other economic pursuits varies widely (Besley and Ghatak 2008). This led some thinkers to suggest that a key reason for low growth in developing countries is their relatively undeveloped system of property rights and, in particular, the limited share of land to which owners have title documents. This, it is claimed, restricts the ability of entrepreneurs and in particular poor individuals to transform "dead assets" into "live capital" through collateralized borrowing (de Soto 2000).

While the motivation from the credit angle is innovative, attention to the government's role in helping to guarantee property rights is hardly a recent phenomenon. From the earliest days of recorded human history, awareness of the social and economic benefits from secure and well-defined land rights and of publicly recorded transactions led many societies to develop customs and laws to define land rights, set up registries to record such rights (often to obtain tax revenue), and establish courts and police to enforce them (Powelson 1988). ${ }^{1}$ The notion that a lack of formal property rights to land may limit the scope for investment and development prompted bilateral and multilateral institutions to sponsor programs that would either systematically register land or improve the functioning of institutions of land administration. ${ }^{2}$

A review of the literature indicates that such interventions did not always live up to expectations. One important insight is that a simplistic and undifferentiated call for "formalization" that lacks awareness of the complexity and long history of existing institutional arrangements is inappropriate and can make matters worse (Bromley 2009). Land titling has also been portrayed as an example of naïve top-down approaches which, rather than responding to real grassroots needs, prescribe "solutions" without a thorough diagnosis (Easterly 2008). While such criticisms may be valid in specific cases, they offer little guidance on how to identify and address situations where there is apparent demand for greater clarity in the definition and exercise of property rights to land. For example, a social as well as economic need for such interventions is apparent in the context of the rapid recent food and commodity price hikes that have lead to demand for land by outside investors, such that failure to define property rights or the inability to enforce them effectively could leave traditional land users in a precarious situation.

In this paper, we examine the theories identifying channels through which land rights can affect socio-economic outcomes, point to realities which often prevent such effects from materializing, summarize quantitative evidence on the actual impact of land registration interventions to assess the validity of theoretical arguments, and derive conclusions that can help guide applied work in this area. 
First we discuss arguments for public involvement in the definition of, and dissemination of information on, property rights in land and how these would, under ideal conditions, affect economic and social outcomes. Then we review real-life situations - such as high inequality in pre-existing power structures and poor governance, imperfections in markets for credit and insurance, high transaction costs, or low land values due to relative land abundance- that may undermine the effectiveness or sustainability of such interventions in specific settings. We then present evidence on the impact (or lack thereof) of land policy interventions on administrative efficiency, tenure security, land-related investment, land values, land market participation, and credit access. We conclude by highlighting the implications for policymakers and the emerging challenges.

\section{The Role of the State in Establishing Property Rights Institutions}

To ensure property rights security and realize the benefits from it, governments need to perform three functions that build on each other, namely (i) unambiguous definition and enforcement of property rights; (ii) provision of reliable information to reduce the transaction cost associated with decisions relating to land markets; and (iii) cost-effective management of land-related externalities.

\section{Definition and Enforcement of Property Rights}

Property rights are social conventions, backed by the enforcement power of the state (at various levels) or the community, allowing individuals or groups to lay "a claim to a benefit or income stream that the state will agree to protect through the assignment of duty to others who may covet, or somehow interfere with, the benefit stream" (Sjaastad and Bromley 2000). How land rights are defined and distributed is a key element of the social fabric, the power structure, and the scope for economic development in a society.

With ill-defined or incomplete property rights, those holding land need to spend resources to defend their rights. As such expenditures (guards and fences) often have little direct social or productive value, they lead to dissipation of rents and divert resources from more productive uses (Allen and Lueck 1992). The privately optimal amount of spending on protection can be excessive from a social point of view (Feder and Feeny 1991; Malik and Schwab 1991; De Meza and Gould 1992). Enforcement of property rights by the state realizes economies of scale and has benefits that are nonrival (that is, one person's enjoyment does not reduce others' benefits), although some of them allow exclusion of others, 
characteristics generally associated with a club good (Shavell 2003; Lueck and Miceli 2006). If property rights are secure, well-defined, and publicly enforced, landowners need to spend less time and resources guarding them.

By reducing the risk of expropriation, secure property rights assure land users of the ability to enjoy the fruits of their labor, thus encouraging them to make long-term land-related investments and manage land sustainably (Besley 1995). Also, ability to verify boundaries at low-cost and legal measures to minimize land-related conflicts reduces transaction costs in a number of ways. Systems to document and verify landownership are public interventions to enhance tenure security. The magnitude of net private and social gains will depend on the extent to which a land registration system induces higher levels of tenure security, and the nature, magnitude, and opportunity cost of the resources thus freed up, compared to the cost of the apparatus needed for administration and enforcement of property rights. ${ }^{3}$

\section{Information Access}

On the basis of well-defined land rights, low-cost access to reliable information on individuals' landownership reduces transaction cost and uncertainty that hinder the exchange of land in markets for rental or sale and the use of land as collateral for credit. Informational asymmetries are less problematic when transactions take place mostly among members of the community who typically are familiar with each other's land rights even in the absence of formal land records, although conduct of land transactions in the presence of witnesses illustrates the importance of publicity to prevent fraudulent or opportunistic behavior. If land transactions extend beyond community members, it becomes more difficult to ascertain who holds legitimate rights and the benefits from formal arrangements increase correspondingly.

If there are differences in the ability of potential transaction partners to make use of land, the ability to transfer land, either through rental or sale, will increase productivity of land use. For example, being able to rent land allows labor to move from agriculture to nonagriculture in the context of economic development. In sales markets, reliable information on landownership can eliminate the risk of future land loss that would be reflected in land prices and the volume of efficiency-enhancing transfers of land.

Provision of credit is risky because uncertainty and asymmetric information lead to credit rationing in equilibrium and reduced lending volumes compared to a world of perfect information (Stiglitz and Weiss 1981). The use of collateral is a universal practice to reduce the extent of credit rationing and improve welfare. Its immobility and relative indestructibility make land ideal collateral. However, the ability of banks to use it for this purpose on a large scale is contingent on a 
formal and low-cost way to identify unambiguously landownership. In the absence of other obstacles to the operation of financial markets, and if land rights can be exercised, a reliable land registry can thus help to increase credit access. As this will allow borrowers to obtain funding for projects, the true risk of which is less than what lenders would assume without collateral, this would increase the level of investment and improve economic efficiency. In such situations, formalizing land tenure can encourage financial market development and use of financial instruments that draw on the abstract representation of property by formal titles (de Soto 2000).

\section{Management of Externalities}

Even in the most individualistic societies, only part of the land is privately owned, and even on such land the rights enjoyed by individual landowners are limited by the need to restrict behavior that negatively affects the broader public interest. One option to accomplish this is for individuals to form user groups or to establish voluntarily norms governing the ability of owners to exercise their rights. Alternatively, authorities can use land information to restrict individual land-use decisions to avoid environmentally or socially harmful outcomes and internalize externalities, for example, through zoning regulations or planning laws. In either case, rules partially restrict individuals' rights (for example, through easements and rights of way), define landowners' obligations to contribute to social objectives (for example, environmental amenities and green space), or set limits on the extent of negative externalities they are allowed to emit. None of these can be enforced without comprehensive and spatially referenced information on landownership and institutional arrangements with clearly assigned responsibilities that cover individual, communal, and state lands so as to facilitate their effective management (Kaganova and McKelar 2006).

As infrastructure and services (water, roads, sewers, electricity) can be provided more cost-effectively if layouts are prepared ahead of time, the planning of land use will be of particular importance if land-use changes from agricultural to residential (or from rural to urban) with economic development. In many parts of the developing world, lack of clear property rights, land information, and institutional or political obstacles limit governments' ability to exercise effectively their functions. This reduces the scope for making land with the necessary services available to individuals in urban areas, who then are driven into informality. Land rights and institutions, including rules regulating governments' powers to exercise eminent domain and impose land-use restrictions, contribute to tenure insecurity and reduce investment incentives in many parts of the world. Clarifying responsibilities and procedures for such actions, and establishing transparent and agile processes for appeal, can increase tenure security, land-related 
investment, and market transactions. Land taxation cannot only provide resources for local governments to deliver public services but also discourage speculation and generate incentives for effective land use (Bird 2004).

\section{Potential Real-Life Complications and Their Implications}

While the above discussion highlights the channels through which land registration systems can generate positive outcomes, such positive impacts are not always observed in practice. A key reason is that ground realities are often quite different from the ideal conditions that implicitly underlie these models in terms of power and governance, relative land abundance and state presence, the costeffectiveness and sustainability of land administration systems, and obstacles to the functioning of credit markets that are widely observed in developing countries. Appreciating the nature and implications of these is essential for being able to diagnose problems in this area and to assess the adequacy of proposed solutions.

\section{Deficient Governance Frameworks}

Conceptual models of land and property rights institutions often abstract from the fact that, in many instances, the distribution of landownership is not the result of the operation of "perfect" markets but reflect power structures. This implies that land registration may be viewed as an attempt to cement existing unequal arrangements rather than to overcome them. Moreover, "good governance"-that is a consistent legal and institutional framework, broad access to information, and competent and impartial institutions (for example, courts and an honest bureaucracy) to enforce rights-is critical for making property rights effective and ensuring that positive impacts from land administration interventions can be realized.

However, many developing countries are characterized by serious deficiencies in governance. In such contexts, the state's monopoly on the exercise of legitimate power, which is a precondition for the functioning of advanced societies and securing property rights, may be abused to appropriate property or to assist in the unfair acquisition of land by elites, thus undermining the security of property rights in a number of respects. The tendency to monopolize land access for other ends was particularly strong in colonial contexts (Binswanger, Deininger, and Feder 1995; Conning and Robinson 2007) and was continued thereafter, especially in situations where land access was highly unequal (Baland and Robinson 2003). This could confine direct benefits from land administration to the better off or imply that land rights remain weak as it would be costly and difficult to enforce them consistently. Politically motivated awards of state land to political leaders or their cronies are an important concern in many countries 
(World Bank 2003; Leuprecht 2004; Government of Kenya 2004). State monopolies over land management in some African countries resulted in high levels of mismanagement and corruption (Mabogunje 1992; Durand-Lasserve and Royston 2002).

Without institutions to enforce property rights effectively, the rights presumably protected by the land registry may exist only on paper and have little practical value. A land registration system can be rendered ineffective by the absence of a judiciary that is accessible and impartial for allowing actions by the state to be challenged effectively, by ineffective government institutions with overlapping mandates that may issue conflicting documents regarding the same plot, and by unclear and contradictory policies that make enforcement unpredictable and costly. In such situations, it would be difficult to rely on state-issued documents and uncertainty of property rights, the elimination of which was the goal of setting up a registry system in the first place. Often, it will be weaker and poorer segments of society which suffer the negative consequences of land titling in situations of ineffective or dishonest government, for example because of the better connections between the wealthy and government officials and the lack of selfenforcing institutions to constrain self-interested but socially undesirable behavior by such elites.

The disadvantages of an inadequate institutional framework can be exacerbated by the high cost of acquiring information on the legal regime or how rights can be enforced. The iniquities and opportunities for abuse that can be created by unequal access to information have been well documented for cases where land rights are adjudicated (Jansen and Roquas 1998; Feder and Nishio 1999). Evidence shows that if first-time registration is introduced, unscrupulous individuals who are well connected and well informed may try to play the system either by speculatively acquiring land in anticipation of formalization-induced price increases or by registering spurious claims to communal or individual land that did not actually belong to them. Lack of access to information can also prevent those who would normally be empowered by certain legislation-often women or members of previously disadvantaged groups-from exercising their rights. Consequently, the inherent opportunities to improve equity-and often also efficiency of land use-may not be fully utilized. In Uganda, for example, laws to augment security of customary rights had the desired impact only when individuals knew about them; but such awareness was very limited (Deininger, Ayalew, and Yamano 2008).

\section{Variation in Land Scarcity}

Particularly if land is relatively abundant and state capacity and outreach are weak or limited, informal mechanisms to secure land tenure may be more 
accessible and less costly to enforce than a formal land administration system. In such cases, decisions on how to respond to demand for formalization will need to be based on careful comparison of the different options available, in particular the governance and transparency of traditional institutions and the political economy and scope for gradual, incentive compatible, and differentiated arrangements to bring about institutional change in response to local needs.

Defining property rights to land, or writing contracts regarding its exchange, is costly, with a major cost element related to the physical survey and verification of boundaries in the field. Therefore, in traditionally settled areas, at low levels of population density, boundaries may be defined only loosely and the first plots to be registered will be those that are subject to transfers, which may involve usufruct rather than full ownership and be confined to community members. In such situations, much of the content of land rights may be defined informally by unwritten "custom". Changing economic and social conditions that make land more valuable and increase the benefits to be obtained from land transfers imply that the value of attributes that have previously been left undelineated may increase sufficiently to offset the transaction costs associated with more precise delineation of land rights.

Numerous examples show that supply-driven establishment of land administration institutions that are intended to-though with limited state presence often not able to-replace traditional actors will at best create a parallel system with the consequence that, instead of complementing each other, "traditional" and "modern" systems compete with each other as was the case in Kenya (Atwood 1990). This will increase transaction costs and give the better off or better informed an opportunity to resort to "institutional shopping", by, for example, pursuing conflicts in parallel through a variety of channels (Firmin-Sellers 2000) and increase conflict (Berry 1997; Fred-Mensah 1999). Doing so could eliminate some of the positive aspects of traditional land administration systems, for example their accessibility and the fact that, under relative land abundance, households may make investments to secure land rights rather than the other way round, implying that — even if it were possible - titling may have little impact on bringing forth new investment (Sjaastad and Bromley 1997; Brasselle, Gaspart, and Platteau 2002). For example, in Côte d'Ivoire there is a long tradition of migrants planting trees to establish property rights over all or part of the land (Colin and Ayouz 2006).

If traditional institutions work relatively well, introducing a system to systematically register land may lead to speculative land acquisition on a large scale and set off a "race for the prize" that can polarize the landownership structure (Benjaminsen and Sjaastad 2002; Peters 2004) as powerful individuals use their informational and other advantages to grab land. For example, with weak governance, land sales by chiefs who reinterpret their trusteeship role as ownership and 
pocket receipts are common and risk undermining traditional social safety nets (Lavigne-Delville 2000). Similarly, "formalized" tenure often eliminated or weakened secondary or communal land rights, for example the right to temporary use of arable land for grazing by pastoralists after the harvest or collection of fuel wood by the poor. Unless measures to recognize, and if necessary record, such rights are taken they may—intentionally or unintentionally—be curtailed in the process of land right formalization, with negative social consequences (MeinzenDick and Mwangi 2009). Also, if land is not the scarcest factor, land registration will be effective only if it is combined with establishment of secure rights to other resources (for example water) that may limit the ability to make productive use of the land. Especially in high-risk environments, individualization of communal land rights that neglects the safety net function provided by flexible patterns of access to land may reduce poor people's options for risk management and insurance and leave everybody worse off (Baland and Francois 2005).

Even if mechanisms for the allocation of rights are established, land transfers pose specific issues because at low levels of development land is not only a productive asset but also performs important functions as a social safety net and old age insurance. Many communities have adopted rules for limiting land alienation to outsiders in an effort to reduce myopic land sales by individuals who would squander the proceeds and then rely on community support for sustenance in a way that creates negative social externalities (Andolfatto 2002). As long as such rules are the product of a conscious choice by the group, and the group has clear and transparent mechanisms for changing the land tenure regime, they are less likely to be harmful. As traditional social ties loosen, or the efficiency loss from the sales restriction becomes too high, groups are likely to move toward a gradual individualization and sell to outsiders. The recent constitutional reform of the land rights system in Mexico provides an example where the fact that the transition toward individual rights can only be made by a 75 percent majority of the whole group provides a safeguard against land grabs. The fact that less than 15 percent of ejidos-mostly those in peri-urban areas where land had de facto already been individualized - made use of this opportunity suggests that, even at relatively high levels of per capita income, the spatial reach of insurance mechanisms to replace the safety net function of (communal) landownership remains more limited than is often thought (Zepeda 2000).

While the specific manifestation of land abundance will depend on the conditions at hand, secular trends such as population growth, urbanization, and increased land demand for nonagricultural purposes - including by outsidersneed to be confronted everywhere. Increasing land scarcity can reinforce pre-existing inequalities along lines of gender, ethnicity, or wealth and set in motion a spiral of conflict, resource degradation, and social strife. These can spread beyond the narrow realm of land and have very negative social and economic 
consequences. For example, in much of West Africa, where the descendants of migrants can be easily identified as "outsiders", increased land values provide a strong incentive for "locals" to renege on earlier sales contracts. In the case of Côte d'Ivoire, land access is interlinked with questions of nationality and the ability of only nationals to own land, which can give rise to conflicts that extend far beyond the area of land (Lavigne-Delville and others 2002). In Rwanda, where extreme land scarcity coincided with accumulation of land by individuals with access to nonagricultural incomes, this has led to land conflict being one of the principal reasons that finally fed into the outbreak of civil war in 1994 (Andre and Platteau 1998).

A number of jurisdictions have recently made provisions for registering communal land (Alden-Wily 2003) and provide opportunities for delimiting community boundaries while leaving registration and management of individual plots to community institutions with the possibility of making the transition to more formal or individualized systems as the need arises. ${ }^{4}$ This is more cost effective than individual titling and allows the covering of much larger areas very quickly and can help reduce neglect of community rights through alienation by outside investors (Alden-Wily 2008), historically a major reason for land-related conflict and strife. If it is combined with mechanisms, and possibly training, for communities to negotiate directly with investors, for example through joint ventures, this can help to decentralize decisions on outside investment and reduce red tape. Recognition of the role of land-use change in accumulation of greenhouse gases (Stern 2008) has sparked a debate about the desirability of establishing mechanisms for compensating land users for positive externalities from certain land-use decisions (for example leaving land forested). Unless property rights by local land users are recognized and recorded in some form, it will be difficult to ensure that such transfers reach those making actual land-use decisions and thus fully affect incentives in the desired way.

While it is important to recognize and build on the advantages of traditional land institutions in terms of cost and accessibility, they should not be idealized in an uncritical fashion. If accountability is weak, increasing pressure on land can quickly erode the advantages of such institutions and so corrupt them, giving rise to conflict (Chimhowu and Woodhouse 2006). For example, land sales by chiefs who reinterpret their trusteeship role as ownership and pocket the receipts are common and risk undermining traditional social safety nets (Lavigne-Delville 2000). Customary systems are well suited to resolving conflicts within a community but face much greater difficulty in reducing conflict across groups, ethnicity, and type of land use such as pastoralists and sedentary agriculturalists (van den Brink, Bromley, and Chavas 1995). Finally, under traditional systems, women are often severely disadvantaged and access to institutions for land administration biased by gender and wealth (Henrysson and Joireman 2007). It is argued that, 
in such contexts, empowering traditional councils without giving minimum standards of accountability to communities, or giving a voice to communities, can actually reduce tenure security as well as gender equality (Claassens 2003; PLAAS and NLC 2003).

The challenge is to find arrangements that combine the advantages of different approaches and to respond to needs flexibly rather than aiming for wholesale replacement. This will require attention to technical, social, and governance issues. Mechanisms to ensure gender equality, transparency, and accountability are critical. Given the limited number of proven models, it will be important to analyze carefully existing arrangements and the scope for improvement on a case by case basis and to analyze the impact of changes in land administration systems based on a proper counterfactual that does not mistakenly attribute (positive or negative) developments that would have happened even without such a step to changes in the land system.

\section{Cost of Service Provision}

A factor with potentially far-reaching impacts on the distribution and sustainability of benefits from land-related interventions is the cost-effectiveness of providing land administration services. Two key factors, in addition to the running costs of registries, are the precision requirements for boundary definitions and the registration methodology applied, with deeds and title systems being most common. A deeds registration system is a public repository where documents for providing evidence of land transactions are lodged, numbered, dated, indexed, and archived. Recording will give public notice of the transaction, serve as evidence for it, and may assign priority to recorded rights in the sense that, in most contexts, registered deeds take priority over unregistered ones, or any deeds registered subsequently. At the same time, registration of a deed does not guarantee the legal validity of the underlying transaction. By contrast, under registration of titles, the register itself serves as the primary evidence of ownership as commonly identified by three attributes, namely (i) the mirror principle indicating that the situation in the registry is an exact reflection of reality; (ii) the curtain principle, implying that anybody interested in inquiring about the title status of a given property will not have to engage in a lengthy search of documents but can rely on the evidence from the title registry being definitive; and (iii) the assurance principle according to which the government will indemnify for damages incurred as a consequence of errors in the registry. ${ }^{5}$

A deeds system is generally cheaper to operate but provides a less comprehensive service as the residual risk of verifying ownership information remains with the transacting parties who incur the cost of due diligence. By contrast, to be able to assume responsibility for the accuracy of information in the registry, the state 
will have to assume responsibility, implying higher set-up as well as operating costs. $^{6}$ As landowners fail to register transactions if the cost of doing so is too high compared to the benefit (that is, the reduction in residual risk) then a title registration system will be socially optimal if land values are high, whereas for lower land values a deeds system is more appropriate (Arrunada 2003). Most land registration projects funded by multilateral agencies recommend adoption of a title registration system-and in some cases even the conversion from a system based on deeds towards one based on title-although this has rarely been substantiated by rigorous analysis of the associated costs and benefits and, possibly as a result, has not always led to the desired outcome. ${ }^{7}$ While a number of well-functioning systems with high land values (Hong Kong, Britain, Scotland, various Canadian provinces) have successfully made the transition from a deeds to a titling system, though often over a long period of time, attempts to shift from a deeds system to one of title registration in developing countries do not have a good record. A project in Sri Lanka failed to put in place the legal, regulatory, and institutional framework for systematic adjudication of land parcels and instead accomplished only a very limited surveying and titling of parcels without conflict, and with only limited economic benefits (World Bank 2007). Measures such as standardization of deeds, parcel-based indexing, compulsory registration, and a requirement for registrars to perform basic checks on deeds and the persons presenting them before accepting them for registration all offer opportunities to strengthen deeds systems. With access to computerized information about the chain of deeds and other instruments pertaining to a given parcel, differences between the deeds and title registration systems have narrowed significantly. From an applied perspective, deeds systems are also more robust and better systems, as in the Netherlands or South Africa, which offer most if not all of the features of well-run titling systems. Even in titling systems, a regulatory framework that fails to disclose relevant rights or encumbrances in the registry can undermine the integrity and usefulness of land registration. In practice, failure to register potentially long-standing rights may allow these to be ignored, causing very negative social impacts. ${ }^{8}$

Resource requirements for first-time registration can also be vastly increased by the fact that the cost of mapping increases exponentially with precision. A widespread confusion between tenure security and precision of measurement, together with lobbying by survey professionals, have often led countries to impose survey standards that exceeded the available implementation capacity and imposed costs that bore no reasonable relationship to land values. Consequently, in many projects with bilateral or multilateral support, costs of first-time registration were very high, sometimes significantly above US\$100 per parcel, with average costs between US\$20 and 60 per parcel (Burns 2007). ${ }^{9}$ This can constrain coverage, outreach, and speed of program implementation, and, even if subsidies support 
first-time registration, can reduce sustainability of such investment if landowners fail to register subsequent transactions.

As most of the benefits from land registries accrue to users, it will be desirable for registries to recover their cost through user fees-although in many countries fees from urban areas with higher frequency and value of transactions are used to cross-subsidize rural areas. In addition to operational inefficiencies, costs are normally increased by three factors, namely (i) unreasonably high precision requirements for surveys; (ii) a need to involve lawyers in transactions; and (iii) stamp duties levied on land transfers. In practice, the costs associated with registering property are by no means trivial; despite reforms to reduce them, the mean in 173 countries included in the World Bank's 2008 "Doing Business" amounts to 6.6 percent of the property values and 81 days of waiting time. The cost of registering property is highly bimodal; while it is 2 percent or less of property value in 32 cases, it amounts to 5 or 10 percent and more of property values in 92 and 41 of the cases (53 and 24 percent), respectively (World Bank 2007). ${ }^{10}$ Informal "fees" can further increase these costs, with possibly far-reaching consequences for the ability of users to access information and their confidence in the land registry. For example, in India, the costs of registering even inheritances are exorbitant and a recent study estimated bribes paid annually on land administration to amount to $\$ 700$ million (Transparency International India 2005), three-quarters of India's total public spending on science, technology, and the environment. To the extent that the costs exceed the benefits (in terms of increased security) which users obtain from registering, high cost can lead to a re-emergence of informal practices up to a point where "deformalization" will undermine the sustainability of a land registry system that was established at high cost (Barnes and Griffith-Charles 2007). The large improvements achieved in Eastern Europe-by making registries financially independent and their information publicly available on the internet, which involves private surveyors, reducing staff, and increasing salaries-highlight the scope for improving efficiency and governance of land registries (Dabrundashvili 2006).

As it will be critical for both the feasibility and continued viability of property rights institutions, the cost of running the land registry system requires upfront attention at the design stage, especially in resource-constrained environments such as Africa. Failure to account for the cost of the proposed institutions is one of the reasons for the failure to implement the provisions of Uganda's 1998 Land Act (Hunt 2004), with the consequence that a decade after its passage not a single certificate was issued. By contrast, in Ethiopia, a low-cost method of certification with high levels of community participation that involved field measurement but not creation of a graphical record managed to register more than 20 million plots at a cost of less than US\$1 per parcel in less than three years. While a system for updating has not been implemented yet, a modest fee (of US\$0.65), 
in line with the users' willingness to pay, would be enough to finance a partly computerized system that could be self-financing. Options for adding at least a cadastral index map at a cost that is sustainable are being explored (Deininger and others 2008). ${ }^{11}$

\section{Credit Market Imperfections}

The discussion thus far has abstracted from imperfections in markets for credit and insurance that may limit the potential of land registration for expanding credit to cover poor farmers in rural areas or to informal (undocumented) landowners in urban areas (many of them illegal squatters in poor slums) - which has been advertised as one of the main advantages of land registration interventions (de Soto 2000). Such imperfections, the effects of which can be exacerbated by socially or politically motivated restrictions on the ability to foreclose or the fact that land-related interventions can reduce the transaction cost of borrowing but are unlikely to increase the availability of "good" and bankable projects, will imply that, in many of the contexts affecting poor or rural populations, the preconditions for the operation of credit markets, in particular the banks' ability to foreclose readily and dispose of land in liquid land markets, will not be met. In such situations, expecting large credit-related benefits from land registration efforts may be unrealistic. Highlighting access to credit, rather than other benefits related to investment incentives or transferability, as the main benefit from land registration, may thus be unrealistic and risk serious subsequent disappointment.

In rural areas of developing countries, covariance of risk, that is the dependence of outcomes on weather and natural phenomena (for example pest attacks), introduces risks that are spatially correlated across large numbers of would-be borrowers and that limit the ability of the lenders to diversify, thus increasing the risk of rural lending. As this implies that a bad outcome will lead to default by many borrowers at once, flooding the land market with foreclosed properties, the value of which may be much diminished, reduces the value of land as collateral. While there are ways to deal with this (for example, spatial diversification of loan portfolios) in the formal market, it does increase transaction costs. $^{12}$ This, together with the transaction costs of collateral registration, may often exceed the benefit that these generate for the relatively small loans undertaken for seasonal (short term) purposes. In many instances, the ability to use land as collateral for credit may thus be limited to larger landowners (Carter and Olinto 2003). ${ }^{13}$

Urban credit markets are typically more developed than rural ones and entail higher participation of private (nonstate) lending institutions. Residential credit often relies on collateralized long-term loans to finance housing acquisition, and documented landownership is important to facilitate such transactions. 
However, use of residential property, in contrast to commercial land, to finance business investments is less common and likely to be constrained, as it will be difficult for banks to repossess low quality dwellings in poor neighborhoods and the gains from selling it will be limited. In both rural and urban areas, credit market effects will also be limited by the availability of promising "bankable" projects as well as the scope for "risk rationing", that is the fact that potential credit-worthy borrowers are unwilling to use titles for fear of losing them in case their project is unsuccessful (Boucher, Carter, and Guirkinger 2008).

\section{Impacts of Land Administration Interventions}

This section provides a review of the extent to which empirical evidence on program impacts supports the notion that, if conditions are right, wellimplemented land registration programs can help improve governance and administrative efficiency, reduce the need to expend resources to enforce land rights and enhance gender equality, increase land-related investment, and enhance operation of land markets as well as credit access. We find that positive impacts are not uniformly observed, in particular that evidence on land-related interventions having improved credit access is less strong and suggests that direct positive impacts on the poor were rather limited.

\section{Improved Institutional Performance and Governance}

Land registration interventions and associated legal reforms are likely to be more effective in a context of good governance, implying that legal and policy changes can independently improve tenure security. The case of land rights reform in China, where land property rights have traditionally been insecure and where increased pressure on land in peri-urban areas gave rise to a series of well-publicized conflicts, provides a good example. The ability of officials to apply eminent domain principles with little public scrutiny, and to rely on readjustment (land reallocation) to acquire large tracts of land without any cash outlay, further imply extensive use of land taking not only as a source of income by local government but reportedly also for individual enrichment and corruption. The 2003 Rural Land Contracting Law includes measures to change the cost of acquiring land by increasing the security of individual land-use rights and enhancing the ability of individuals to lodge appeals against violation of such rights. Data from a representative nationwide survey suggest that legal reform had a significant and quantitatively important impact on increasing the security of property rights in terms of reducing the probability of "illegal" land reallocation and increasing the amount of payments received by those who were affected by legitimate land takings. Legal reform had a significant impact 
only where the village leadership was elected, suggesting that, for legal reform to be effective, ways of holding the state to account are needed, an interpretation that is supported by the fact that the knowledge of village leaders of the law had an independent impact on reducing the probability of illegal reallocation. Availability of land-use certificates did not significantly reduce the risk of an unauthorized land reallocation, suggesting that such certificates will only be useful within an appropriate institutional framework (Deininger and Jin 2009).

A natural experiment where title was given to some but not to other urban squatters who had started out in exactly the same conditions in Buenos Aires allows assessment of the impact of land registration not only on economic outcomes but also on attitudes and beliefs. Some 14 years after the intervention had occurred, those who, by chance, had benefited had significantly more individualistic and materialistic attitudes, a result that is very robust. ${ }^{14}$ The effect is not negligible, being equivalent to an additional 4.4 years of education by the household head. Despite their much inferior socio-economic situation, the beliefs of beneficiaries are virtually indistinguishable from the population average. By comparison, attitudes by those who did not get regularized are consistent with what one would expect based on their socio-economic characteristics (Di Tella, Galiani, and Schargrodsky 2007).

Land registration can also have an affect on the local government's ability to generate resources, its governance, and the efficiency of its service provision. In the Indian state of Karnataka, computerization of textual records is estimated to have saved users \$16 million in bribes annually (Lobo and Balakrishnan 2002). Using this as a basis to automate registration and the associated valuation allowed cuts in stamp duty from 14 to 8 percent and quadrupled tax revenue from $\$ 120$ to $\$ 480$ million, thus illustrating the scope for land registries to be selffinancing. ${ }^{15}$ In Mexico, before reforms wee initiated in 1992, the ejido sector was subject to numerous restrictions on land rights and the rural economy was characterized by clientelism, inefficient land use, and low levels of investment, and peri-urban areas were subject to chaotic informal settlement (Gordillo, de Janvry, and Sadoulet 1998). In qualitative interviews, beneficiaries of a program to establish land rights that were both more secure and better administered highlighted that the two most important aspects of the reforms were their impact on reducing conflicts and on increasing transparency, with the associated reduction of political influence in the ejido (World Bank 2002). Based on promising results from earlier pilots, Ethiopia embarked on large-scale and highly participatory registration of land holdings by six million households in 2003-05. Although land remains state-owned and many restrictions on land transfers continue to exist, more than 80 percent of respondents in a nationwide survey indicated that certification (i) increased the chance of getting compensation in the case where land was acquired for nonagricultural uses; (ii) helped to reduce conflicts; and (iii) especially in 
regions where a woman's photograph was included on the land certificate, improved the bargaining power of females (Deininger and others 2008).

\section{Lower Private Spending on Defending Property Rights}

In Peru, a large land titling effort was carried out in rural and urban areas. Estimates indicate that, in urban areas, having received a title resulted in a significantly increased perception of tenure security. Furthermore, there was a large labor supply response as recipients of titles increased their participation in the formal labor market, because they were no longer required to invest in a multitude of informal activities required to maintain tenure security (Field 2007). The magnitude of these effects is large and grows over time with labor supply estimated to have increased to 45 hours (equivalent to 50 percent of the total) after four years, in marked contrast to other welfare programs that generally reduce labor-force participation. As adults have an advantage over children in protective activity, a reduction in the need for home protection could also reduce the demand for child labor. Moreover, to the extent that changes in tenure security can bring about an independent reduction in the productive value of children (for example, due to better old age insurance or credit access or due to increased bargaining power by females as compared to males), they could also prompt a reduction in child bearing.

The fact that, in the same program, a requirement was imposed for titles to be issued jointly in the names of husband and spouse provides an opportunity to test for gender-specific effects. If the titling program led to a redistribution of household assets in favor of females that shifted intrahousehold bargaining power, one would expect outcomes more favorable to them. ${ }^{16}$ This is consistent with a 22 percent reduction of fertility for squatters who received a property title and the fact that females who received joint title experienced twice the reduction in the probability of having a child than those where the title is in one name only (Field 2003). A study in Nepal finds positive association between higher levels of women's land rights and their socio-economic empowerment, as well as the health of their children, and concludes that the impact of landownership is comparable in magnitude to that of education and employment (Allendorf 2007). This is in line with evidence from India where access to land allows women to choose self-employment on their land, thereby escaping gender discrimination in the wage labor market (Deininger, Jin, and Nagarajan 2006), something that is supported by qualitative evidence on the importance of land for the social status of women (Panda and Agarwal 2005). In Punjab, joint titling made women more assertive of their rights, increased attachment to their homes, and enabled them to use formal means (courts) rather than informal ones to assert ownership claims against hypothetical sales by their husbands (Datta 2006). In Gujarat, 
landownership was found to be a key determinant of women's empowerment that increased a self-stated propensity to invest in land (Baruah 2007). The magnitude of the investment effects associated with insecure land rights for women, as well as the complexity of the underlying relationship, is illustrated for Ghana (Goldstein and Udry 2006). All of this points toward potentially important gendered impacts of land titling that sometimes materialize in rather unexpected ways.

In the long term, an additional channel through which land registration could affect household size is through the scope for members of the extended family to separate their inheritance, move out, and start independent enterprises. Indeed, in Buenos Aires, similar findings of reduced family size - via lower presence of extended family members - and lower fertility, as well as improved educational outcomes by children of titled vs untitled squatters, are found (Galiani and Schargrodsky 2005). While there were no differences in the number of children born before treatment, untitled households are much larger ones-due to the presence of members of the extended family - and there are larger numbers of children after titling, an effect that disappears for the late treatment group. If household resources for education are fixed, the lower number of children could provide opportunities for investment in human capital. Indeed, children of titled squatters had levels of school attendance that were 0.4 days per week above those of the control group and a level of school achievement that was higher by 0.42 years. This is roughly equivalent to the estimated impact of Progresa in Mexico, suggesting that land registration can have potentially large effects. (Progresa is a Mexican government program (whose name was changed later to Oportunidades) which makes cash grants to poor families on the condition that recipients abide by certain requirements regarding preventive health, nutrition and child school enrollment.)

Also, teenage pregnancy rates and children's short-term nutritional indicators (weight for height but not height for age) are better on titled as compared to untitled parcels, which suggests that titling allows families to improve investment in human capital (Galiani and Schargrodsky 2004).

\section{Investment in Land Improvements and Increased Land Values}

The hypothesis of positive tenure security effects on economic incentives is hardly controversial and has been quantitatively demonstrated by numerous recent studies, for example in China (Jacoby, Li, and Rozelle 2002), Latin America (Kazianga and Masters 2006; Bandiera 2007), Africa (Deininger and Jin 2006; Goldstein and Udry 2006), and Eastern Europe (Rozelle and Swinnen 2004). What is debated is whether, and under what circumstances, land registration programs can effectively enhance tenure security, especially in relatively 
land-abundant settings, and how they need to be best designed. Existing evidence as to the potential gains from titles is not uniform. A study in a rice growing area in Madagascar suggests that formal title had no effect on plot-specific investment and little impact on productivity. Land values are estimated to increase by at most 6 percentage points due to titling, implying that the cost of land titling will have to be very low for such a measure to be justified economically (Jacoby and Minten 2007). Within-household analysis of new investments on owned as compared to merely occupied (mailo) plots by owner-cum-occupants in Uganda, by contrast, points to significant and quantitatively large investment effects of full ownership: shifting from mailo occupancy to ownership is predicted to double the likelihood of soil conservation and increase that of tree investment fivefold. Tenant registration is estimated to have no investment effect while measures to strengthen occupancy rights attenuate - but fail to eliminate fully-investment disincentives originating in overlapping rights (Deininger and Ali 2008). In Ghana, tenure insecurity is shown to lead to reduced investment in the form of fallowing, estimated to reduce output by about one-third and to lead to very large aggregate efficiency losses (Pande and Udry 2005). While this supports the importance of secure land tenure as a precondition for growth, it suggests that the magnitude of possible impacts can vary widely and that interventions aiming to increase tenure security need to be context specific to be effective.

In urban areas, an important indicator for effectiveness of titling programs would be housing investment. Indeed, in Buenos Aires, regularized squatters have a 40 percent higher probability of having good walls and a similar increase in the probability of having good overall housing quality. Apparently, the shift from use to ownership rights increased the incentive to invest but failed to make households richer or increase the transferability of their assets (Galiani and Schargrodsky 2005). In Peru, evidence on improvements in housing between 1994/95 and 1999/2000 suggests that, for titled households, rates of house renovation increased more than two-thirds above baseline levels, though most of the increase was financed out of pocket rather than through credit (Field 2005).

Applying the same methodology to rural households in Peru, and distinguishing households with different initial levels of tenure security, land titling was found to have contributed to significantly increased investment, particularly for initially insecure households for whom the propensity to invest in land almost quadrupled. This is consistent with findings for a smaller region in Peru where registration increased the probability of investment by 6.6 percent (Antle and others 2003). As the vast majority (97 percent) of such investments was financed out of pocket, a big credit impact is improbable (Fort 2007) and the fact that the titling density within a district significantly affected infrastructure investment points toward external effects. Use of a linear probability model of export crop adoption in a small panel suggests that receipt of title had a highly significant and positive effect on its own and-less 
robustly - made households more responsive to price changes, leading the authors to the conclusion that market liberalization helps only if conducted in an appropriate institutional environment (Field, Field, and Torero 2006).

If adjustments are made for effects of risk and imperfections in capital markets, the difference between the price of registered and unregistered land can provide a measure of the social welfare gains of land registration (Feder and Feeny 1991). In Nicaragua, full registration of a plot after the 1990 revolution had a significant investment-enhancing impact, increasing the propensity to invest by between 8 and 9 percent. By contrast, award of agrarian reform title without registration had insignificant effects. Moreover, with about 29 percent, marginal returns to land-attached investment are much higher than those from investment in mobile capital, pointing toward scope for gains in economic efficiency by shifting resources from the latter towards the former and suggesting that such higher levels of tenure security can promote a more appropriate balance in the investment mix between moveable and fixed capital. Land values for plots with registered title are higher by 30 percent (Deininger and Chamorro 2004). Reduced form regressions lead to similar conclusions regarding the superiority of full as compared to only "reform" title and enhanced land values, investment in perennials, and higher crop yields (Broegaard 2005). The presence of an investment incentive effect that is independent from credit is also highlighted by evidence from a land settlement program in Guatemala that was started in 1986. A 1993 resurvey suggests that, while all of the sample households had benefited from credit provided under the program, those who had exogenously received a title to their property took greater care of their parcels and, most likely as a result of past and recurrent investment, had higher yields than those who did not (Schweigert 2007).

In addition to awarding about 11 million land use certificates (LUCs) through land registration efforts in the 1993-2000 period, legal changes in Vietnam during the same period also expanded users' rights to include transfer, inheritance, exchange, lease, and mortgage (Do and Iyer 2008). While the magnitude of new registration was comparable to the Ethiopian case, it is much larger and more rapid than what was achieved by other interventions such as the 8.7 million titles distributed in Thailand since the 1980s, the 1.8 million titles in Indonesia from 1996, and the 1.2 million urban and 1.5 million rural titles in Peru between 1992 and 2005. A difference in difference estimation strategy at district level for this case suggests that provinces where certification made more progress have devoted more of their land to perennials and have expanded nonfarm activities. In a province where everybody had an LUC, the proportion of land under perennials is predicted to be 7.5 points higher. As restrictions on crop choice that require households to keep land in rice remained in effect, this is likely to be a lower bound on the true effect. Of equal interest is the fact that the supply of labor to nonagricultural employment is estimated to increase by 11-12 
weeks compared to the situation without LUC, an outcome that is more pronounced for the poor than the rich. Much of this effect is through diversification of the income portfolio within households rather than specialization by households in different types of activities. There is, however, no evidence of either a credit effect or a measurable impact of titling on income or expenditure, consistent with the notion that, without complementary changes in banking and rules for land transactions, titling alone is unlikely to set off big changes in economic structure.

Although little time had passed for certification to have a long-term effect, a significant impact emerged not only on households' perceived tenure security (an 18 percentage point reduction in the share of those expecting an administrative change to their land holding over the next five years) but also on land-related investment (a 29 point increase in the likelihood of having made repairs or new investments in the last 12 months) and a 9 percentage point increase in the propensity of renting out land (Deininger, Ali, and Alemu 2008).

In Thailand landownership titles induced higher investment in farming capital (attached investments and other capital), and titled land had significantly higher market values and higher productivity per unit. Output was 14-25 percent higher on titled land than on untitled land of equal quality (Feder and others 1988). A comparison of housing prices between nonsquatter, formal residential areas and the informal areas of the city of Davao in the Philippines revealed that prices were 58 percent higher in the formal area than in the informal one and that rents were 18 percent higher; in Jakarta, registered land was up to 73 percent more valuable than similar land held by a weak claim (Friedman, Jimenez, and Mayo 1998).

Self-assessed land values provide an upper bound on the gain in utility from property registration. In Ecuadorian slums, title increases the expected market value of a plot by 23 percent (based on responses by the same household for hypothetical changes), an effect that increases to more than 50 percent in situations where, because the settlement was recently invaded and has no organizer who could provide political protection, tenure security is very low. Comparing the hypothetical benefits to the cost of such a program suggests a positive return even though one has to take into account the tendency for private people to overvalue the gains from title. Particularly large benefits to households with women only are interpreted as indicating that there is a need for interventions to incorporate gender concerns (Lanjouw and Levy 2002).

\section{Land Market Functioning}

In China, land rental contributed to diversification of the rural economy (Deininger and Jin 2009) and productivity. However, if land rights are not 
sufficiently secure, landowners may be averse to renting out because they fear that land may be taken away from them (Yang 1997; Holden and Yohannes 2002) or that tenants may not give it back upon expiry of the contract. This reduces the level of transactions below the optimum and can lead to significant losses in allocative efficiency (Benjamin and Brandt 2002). Within-household regressions and cross-sectional estimates in Vietnam suggest that having longterm use rights secured through registration will increase the tendency to rent out to nonrelatives but does not affect the propensity to rent out to relatives, consistent with the notion that land registration can substitute for informal enforcement through social capital. Moreover, and in line with the expectation that in the case of informal transactions with friends and relatives the smaller number of potential partners reduces the scope for efficiency-enhancing transactions, rental transactions among nonrelatives but not among relatives are shown to contribute to a significant increase in efficiency (Deininger and Jin 2008).

In the Dominican Republic, insecure property rights not only reduce the level of activity on the land rental market, but also induce market segmentation. Landlords who have reasons to fear losing their land restrict renting to narrow local circles of confidence. This segmentation further reduces rental activity by limiting opportunities to find suitable tenants. Simulations show that improved security of property rights through title registration can lead to efficiency and equity gains; improving tenure security would increase total area rented by the poor by 63 percent (Macours, de Janvry, and Sadoulet 2004). In Nicaragua producers who have a title are significantly more likely to rent out their land, providing an opportunity for more effective producers to increase their cultivated area (Deininger, Zegarra, and Lavadenz 2003). On the other hand, descriptive statistics from Peru suggest that perceived rights to rent, sell, or exclude others-in contrast to rights to use, invest, and inherit-are not significantly different between titled and nontitled households (Fort 2007).In Tigray, Ethiopia, land certification contributed to higher levels of land-rental market participation, especially by female-headed households (Holden, Deininger, and Ghebru 2008) and considerably enhancing opportunities for women to benefit from land rental (Bezabih and Holden 2006). As it makes it easier to liquidate and recoup the full value of investments in case of unexpected shocks (Ayalew, Dercon, and Gautam 2005; Deininger and Jin 2006), transferability is likely to increase investment incentives. Renting out allows landowners to take up nonfarm jobs without losing their assets or closing off the possibility of returning to farming and allows tenants to increase incomes by cultivating larger areas (Carter and Yao 2002; Kung 2002; Deininger 2003). Registered documents to prove ownership can help remove the perceived risk of engaging in transactions by lowering enforcement costs in cases of dispute, thus allowing more rental transactions, possibly at a lower rental price. 
Studies on the potential impacts of land registration on sales markets have mostly been based on descriptive comparisons of the situation before and after interventions. In Eastern Europe, registration of land rights was generally followed by considerable and often rapid growth in land market transactions and, in the case of urban land and real estate, mortgages, but construction of a counterfactual is difficult, and therefore the evidence is only suggestive. In Vietnam, allowing land sales has led to increased activity and sales markets and even landlessness, but this has not increased poverty; to the contrary, it has overall been a benign or even positive factor in the process of poverty reduction (Ravallion and van de Walle 2008). In St Lucia, sales market activity and the number of registered mortgages increased immediately after introducing the system (and remained high in peri-urban areas). However, the marginal increase in formal land market activity after introduction of the title system was not sustained over time (Barnes and Griffith-Charles 2007), pointing toward rather limited impacts. Descriptive evidence suggests that titling of frontier land in Guatemala, while helping to reduce conflict and reduce the perceived danger of the land invasion, has little effect on investment and credit access and fails to prevent informal sales, implying that the registry is becoming outdated (Gould 2006).

\section{Access to Credit}

Early study of the impact of titling in Thailand, where informal credit markets had already operated and land markets functioned relatively well before the intervention, point toward significant impacts on credit access (Feder and others 1988). In Paraguay, a significant credit supply effect was demonstrated but accrued only to medium and large landowners, whereas producers with less than 20 hectares remained rationed out of the credit market, something that could set in motion longer-term dynamics in terms of equity that may not be desirable (Carter and Olinto 2003), parallel to what was found in Guatemala (Mushinski 1999). However, if land markets are illiquid or nonexistent, or if the cost of registering mortgages or foreclosing on them is very high, one would not expect land registration to have an immediate impact on credit access. For example, in Peru, land registration increased the likelihood of obtaining a loan (by between 9 and 10 percentage points) only for credit through a state bank but not the private sector. One explanation is that, due to the political nature of the application process, the likelihood of foreclosure is actually lower (or transaction costs higher) for those with titles. In fact, there is some reason to believe that the politicized nature of the titling process may actually have reduced rather than increased the ability of banks to foreclose. This is in line with evidence suggesting that, even after land registration, more than one-third of households remained completely 
rationed out of formal credit markets (Field and Torero 2006). While interest rates charged by the private sector are lower (by about nine points) for titled as compared to untitled households, this appears to be due to signaling rather than the ability to collateralize debt with collateral, similar to what is found in Indonesia where land registration was contingent on demand and significant payment by owners so that possession of a title could be used as a proxy for entrepreneurial drive (Dower and Potamites 2005). Evidence from rural areas in Peru points in the same direction (Field, Field, and Torero 2006; Fort 2007). In Buenos Aires, despite significant effects on house-related investment and other variables, no credit effect is found, implying that, even with titles, households will be unable fully to ensure their consumption or use their talents more efficiently in entrepreneurial activity, suggesting that growth implications of titling programs may be overstated (Galiani and Schargrodsky 2005), consistent with what is found by a recent comprehensive descriptive review of urban titling (Payne, Durand-Lasserve, and Rakodi 2008).

\section{Policy Implications and Challenges Ahead}

Our review allows a number of conclusions. First, realization and nature of benefits from land registration depend on the broader socio-economic and governance environment and the nature of interventions. Bad governance and an ineffective or predatory state will hinder benefits from such interventions, or even cause negative outcomes. However, there is ample evidence of positive tenuresecurity effects of land registration in situations where overall conditions are favorable. These effects manifest themselves in higher levels of investment, less need for activities to protect land rights, and-especially if female rights are enhanced or made more visible-empowerment of women. Second, while there is evidence of land registration helping to activate land rental markets, the relationship between land tenure and off-farm labor market participation is underresearched, especially in rural areas of developing countries where occupational diversification will acquire increased importance as a driver of growth in the immediate future. Third, although land registration helps to improve credit access in some settings, positive credit effects are contingent on other factors such as liquidity of land markets and the presence of credit-worthy projects that may not hold in practice. Even if credit effects materialize, evidence on potentially very skewed incidence of such effects suggests that attention to their distribution will be warranted. Fourth, evidence on the cost-effectiveness, sustainability, and longer-term impact of land administration interventions is limited and few quantitative studies have explored how land registration effects can be enhanced by complementary interventions (for example business training) and how they 
interact with the broader social and economic environment. Finally, although one would expect impacts of systematic land registration to be more pronounced in urban environs where such interventions may be highly complementary to infrastructure investments (Gulyani and Talukdar 2008), quantitative studies have focused on rural areas and examined land regularization almost exclusively in terms of allocation of individual rights, neglecting group rights and state land management.

This suggests that, instead of using "formalization" as a panacea, interventions to improve property rights will have to be preceded by a careful diagnosis of the policy and governance environment. The need to adapt flexibly to local conditions and the absence of standard approaches require careful monitoring to learn from experience - possibly drawing on experimental methods and standard administrative data. At the same time, there are a number of clear implications to guide policymakers and practitioners.

First, the positive impact of low-cost and participatory measures to increase tenure security suggests that, even where credit markets are underdeveloped and the provision of individual titles in a rather slow and costly process will not be viable economically, a number of measures are available to make land rights more secure. These include a legal framework that recognizes traditional rights by individuals and groups, dissemination of information, institutional reform, and registration of rights - possibly first at the group rather than the individual level-in a way that can be subsequently upgraded according to clear rules, with information maintained in a coherent format to avoid parallel systems. Safeguards, such as systematic rather than sporadic registration, information campaigns on laws, procedures, and ways of redress, as well as public review of allocations before finalization, will be essential.

Second, the technical complexity of some of the underlying functions should not conceal the importance of land administration institutions delivering services (that is, information useful to clients) in a cost-effective way. There is no reason why standard indicators of outreach and effectiveness of service delivery should not be applicable to land administration. Benchmarks such as coverage, registered transactions as a share of parcels, and cost per transaction will be important to guide policy choices as a diagnostic tool to identify areas for improvement and to generate political support for measures to improve outcomes.

Third, good governance is of overriding importance to ensure that clear property rights and institutions to administer them contribute to the desired socioeconomic outcomes instead of providing a means to enable elites and officials to usurp the rights of the poor and socially weak groups. This requires clear delineation of institutional responsibilities within the land administration system, an audit of regulatory requirements to ensure that these are justified and that compliance is within the reach of target groups, transparent management and access 
to information, effective avenues to flag problems, and availability of accessible and accountable institutions to resolve conflicts and ensure enforcement.

\section{Funding}

Support from the collaborative DFID-World Bank program on land policies, the Gender Action Plan TF, the Norwegian ESSD Trust Fund (Environment Window), and the Lincoln Institute for Land Policy is gratefully acknowledged.

\section{Notes}

Klaus Deininger: Development Research Group, The World Bank, Washington DC, USA; Tel. 202 4730430; fax 202522 1151; email kdeininger@worldbank.org (Corresponding author). Gershon Feder: International Food Policy Research Institute, Washington DC, USA. The authors thank Xiangping Liu for excellent research assistance and C. Augustinus, A. Durand-Lasserve, S. Galiani, S. Holden, G. Ingram, J. Kagwanja, G. Kohlin, J. Sanjak, and H. Selod for discussion and insightful comments. The paper draws heavily on a literature review presented at the 2008 International Land Policy Conference by the Lincoln Institute for Land Policy and the Swedish Royal Academy of Agricultural Sciences (to be published in a proceedings volume). The views expressed in this paper are those of the authors and do not necessarily reflect those of the World Bank, its Board of Directors, or the countries they represent.

1. Documented evidence on the operation of property rights institutions is available from as early as 2350 BC from Egypt, the Assyrian empire in Mesopotamia (c.1200-750 BC), and its successor the Babylonian and Sassanian (500 BC-AD 651) empires (Powelson 1988).

2. Activities related to the demarcation and survey of land boundaries, registration and record keeping, adjudication of rights, resolution of conflicts, and land management are normally referred to as "land administration" (UNECE 1996). In 2005, the World Bank was supervising a portfolio of more than 1 billion US dollars' worth of land administration projects.

3. While much of the literature relies on a unitary household model, women's ability to own land is often constrained by social practice. Even if constitutions outlaw gender discrimination, females can often access land only through male relatives, and their ability to inherit land or hold on to it in the case of widowhood or divorce is limited. This can affect their intrahousehold bargaining power, the allocation of household spending among alternative uses, the efficiency of land use (Udry 1996), and the participation in nonfarm opportunities (Quisumbing and Maluccio 2003). Legal changes and land registration programs that take into account local realities and enforcement capacity can contribute to women's social and economic empowerment (Deininger and Castagnini 2006; Joireman 2008).

4. For a discussion of institutional options see Fitzpatrick (2005) and for a detailed example of legislative arrangements to put this in practice see Government of Mexico (2000).

5. To illustrate this: if, under title registration, A fraudulently sells a piece of land (which actually belongs to C) to B who purchases in good faith, B becomes the rightful owner and any claims by $\mathrm{C}$ are extinguished as soon as the sale is registered. The only recourse open to $\mathrm{C}$ would be to demand compensation, but not restitution of the property, from the state which in turn has the option to sue A. The need to ensure that the responsibility taken up by the state can be met is one of the reasons why title registration systems are normally associated with a guarantee fund to facilitate payment of such compensation. By contrast, under a deeds system, it is B's responsibility to investigate the veracity of A's ownership claims and $\mathrm{C}$ will be able to demand restitution of the property from B, implying that B will incur the loss. 
6. The specific historical circumstances of the United States, which operates under a deeds system, have given rise to a system of "title insurance" where private companies, rather than the state, have developed a comprehensive record of all land transactions that enables them to examine the legal validity of transactions and insure against defects. Given the long time it took to assemble the required information this is not an option for developing countries (Arrunada and Garoupa 2005).

7. In St Lucia, households received provisional documents that were supposed to be replaced by full titles after 12 years, but 75 percent of titles were never collected by their owners (Griffith-Charles 2004). In Ghana, where a new title registration system has been introduced, less than 1,000 titles were issued per year and the rate at which titles entered the system was below that of new transactions to be registered, implying a widening gap between the registry and reality and increasing levels of informality (Nettle 2006).

8. An illustrative example relates to tenants on mailo (merely occupied) land in Uganda. Although these tenants had in many cases been on the land for more than a generation, their presence was not indicated on landlords' titles. Banks who lent against such titles discovered that the presence of tenants with far-reaching rights on the land they had accepted as collateral made liquidation impossible, making it difficult even for owners of unencumbered land to use it as collateral, thereby undermining the value of existing titles and making the state guarantee (which extends to ownership only) worthless from their point of view (Deininger and Ali 2008).

9. In the Philippines at the start of the 20th century, an explicit policy to survey the country and establish a title registration system failed in large part as a result of the high cost of surveying. Public support to a nationwide program to establish land titles would have amounted to between 57 and 230 percent of the colonial government's entire revenue (Maurer and Iyer 2008), thus highlighting the importance of ways to keep down costs.

10. The World Bank's 'Doing Business' survey has rightly identified the cost of registering property as a key impediment to private sector activity by including this as one of the indicator variables in its global survey. As these figures are based on expert opinion for an unencumbered property in the capital city, they should be used only with proper care (Arrunada 2007) and are likely to constitute a lower bound for the cost of registration faced by the average landholder. For example, a field-based study in St Lucia found transaction costs for what was considered a "typical" transaction by the local population to be almost three times the 7 percent given in the Doing Business survey (Griffith-Charles 2004).

11. Of households who do not have one, 95 percent would like to get a certificate; 99 percent of those with a certificate would be willing to pay an average of 12 Birr (\$1.50) to replace it if it were lost; and 90 percent (most of them willing to pay) would like to add a sketch map (Deininger and others 2008).

12. Policy-induced restrictions on the transferability of land can further increase the transaction cost associated with use of formal land records as a means to improve credit access, as is the case in Tanzania.

13. To reduce transaction costs, informal and even formal, lenders sometimes invoke a procedure that is not fully formal, whereby they demand physical possession of the title document. This does not entail formal recording of collateral encumbrances, but it prevents the borrower from selling the land under favorable (formal) terms to others without respecting first the obligations to the creditor (Siamwalla 1990).

14. Among others, they were more likely to believe that people can succeed economically on their own, that money is important to be happy, and that others can be trusted. No significant differences emerge regarding the belief that those who put in effort will do better economically.

15. In Thailand a program of land titling provided the basis for a substantial increase in the total amount of land revenue collected, from US\$300 million in 1984 to US\$1.2 billion in 1995 (Burns 2007).

16. A similar nutritional effect, though only on children's weight but not height, is found in another study using the same data (Vogl 2007). 


\section{References}

Alden-Wily, L. 2003. "Governance and Land Relations. A Review of Decentralization of Land Administration and Management in Africa." IIED Issues Paper 120. London: International Institute for Environment and Development.

2008. "Custom and Commonage in Africa: Rethinking the Orthodoxies." Land Use Policy 25(1):43-52.

Allen, D., and D. Lueck. 1992. "Contract Choice in Modern Agriculture: Cash Rent versus Cropshare." Journal of Law and Economics 35(2):397-426.

Allendorf, K. 2007. "Do Women's Land Rights Promote Empowerment and Child Health in Nepal?" World Development 35(11):1975-88.

Andolfatto, D.. 2002. "A Theory of Inalienable Property Rights." Journal of Political Economy 110(2): 382-93.

Andre, C., and J.P. Platteau. 1998. "Land Relations under Unbearable Stress: Rwanda Caught in the Malthusian Trap." Journal of Economic Behavior and Organization 34(1):1-47.

Antle, J.M., D. Yanggen, R. Valdivia, and C. Crissman. 2003. "Endogeneity of Land Titling and Farm Investments: Evidence from the Peruvian Andes." Working Paper. Bozeman, MT: Montana State University.

Arrunada, B. 2003. "Property Enforcement as Organized Consent." Journal of Law, Economics, and Organization 19(2):401-44.

2007. "Pitfalls to Avoid When Measuring Institutions: Is Doing Business Damaging Business?" Journal of Comparative Economics 35(4):729-47.

Arrunada, B., and N. Garoupa. 2005. "The Choice of Titling System in Land.” Journal of Law and Economics 48(2):709-27.

Atwood, D.A.. 1990. "Land Registration in Africa: The Impact on Agricultural Production." World Development 18(5):659-71.

Ayalew, D., S. Dercon, and M. Gautam. 2005. "Property Rights in a Very Poor Country: Tenure Insecurity and Investment in Ethiopia." Global Poverty Research Group Working Paper Series, GPRG-WPS-021, Oxford University.

Baland, J.M., and P. Francois. 2005. "Commons as Insurance and the Welfare Impact of Privatization." Journal of Public Economics 89(2-3):211-31.

Baland, J.M., and J.A. Robinson. 2003. "Land and Power." Discussion Paper 3800, London: Centre for Economic Policy Research.

Bandiera, O. 2007. "Land Tenure, Investment Incentives, and the Choice of Techniques: Evidence from Nicaragua." World Bank Economic Review 21(3):487-508.

Barnes, G., and C. Griffith-Charles. 2007. "Assessing the Formal Land Market and Deformalization of Property in St Lucia." Land Use Policy 24(2):494-501.

Baruah, B. 2007. "Gendered Realities: Exploring Property Ownership and Tenancy Relationships in Urban India." World Development 35(12):2096-109.

Benjamin, D., and L. Brandt. 2002. "Property Rights, Labour Markets, and Efficiency in a Transition Economy: The Case of Rural China." Canadian Journal of Economics 35(4):689-716.

Benjaminsen, T.A., and E. Sjaastad. 2002. "Race for the Prize: Land Transactions and Rent Appropriation in the Malian Cotton Zone." European Journal of Development Research 14(2): $129-52$.

Berry, S. 1997. "Tomatoes, Land and Hearsay: Property and History in Asante in the Time of Structural Adjustment.” World Development 25(8):1225-41. 
Besley, T.. 1995. "Property Rights and Investment Incentives: Theory and Evidence from Ghana." Journal of Political Economy 103(5):903-37.

Besley, T., and M. Ghatak. 2008. "Creating Collateral: The de Soto Effect and the Political Economy of Legal Reform.” Working Paper, London School of Economics.

Bezabih, M., and S. Holden. 2006. "Tenure Insecurity, Transaction Costs in the Land Lease Market and their Implications for Gendered Productivity Differentials.” Paper presented at the 26th International Conference of the International Association of Agricultural Economists, Brisbane, Australia.

Binswanger, H.P., K. Deininger, and G. Feder. 1995. "Power, Distortions, Revolt and Reform in Agricultural Land Relations." Handbook of Development Economics 3B:2659-772.

Bird, R.M. 2004. International Handbook of Land and Property Taxation. Cheltenham, UK: Elgar.

Boucher, S., M.R. Carter, and C. Guirkinger. 2008. "Risk Rationing and Wealth Effects in Credit Markets: Theory and Implications for Agricultural Development.” American Journal of Agricultural Economics 90(2):409-23.

Brasselle, A.S., F. Gaspart, and J.P. Platteau. 2002. "Land Tenure Security and Investment Incentives: Puzzling Evidence from Burkina Faso." Journal of Development Economics 67(2): $373-418$.

van den Brink, R., D.W. Bromley, and J.P. Chavas. 1995. "The Economics of Cain and Abel: Agropastoral Property Rights in the Sahel." Journal of Development Studies 31(3):373-99.

Broegaard, R.J. 2005. "Land Tenure Insecurity and Inequality in Nicaragua." Development and Change 36(5):845-64.

Bromley, D.W. 2009. "Formalising Property Relations in the Developing World: The Wrong Prescription for the Wrong Malady." Land Use Policy 26(1):20-7.

Burns, T.A. 2007. "Land Administration: Indicators of Success and Future Challenges." Agriculture and Rural Development Department, World Bank, Washington.

Carter, M.R., and P. Olinto. 2003. "Getting Institutions 'Right' for Whom? Credit Constraints and the Impact of Property Rights on the Quantity and Composition of Investment." American Journal of Agricultural Economics 85(1):173-86.

Carter, M.R., and Y. Yao. 2002. "Local versus Global Separability in Agricultural Household Models: The Factor Price Equalization Effect of Land Transfer Rights.” American Journal of Agricultural Economics 84(3):702-15.

Chimhowu, A., and P. Woodhouse. 2006. "Customary vs Private Property Rights? Dynamics and Trajectories of Vernacular Land Markets in sub-Saharan Africa." Journal of Agrarian Change 6(3): $346-71$.

Claassens, A. 2003. "Community Views on the Communal Land Rights Bill.” Research Report 15. Cape Town: Programme for Land and Agrarian Studies, University of the Western Cape.

Colin, J.P., and M. Ayouz. 2006. "The Development of a Land Market? Insights from Cote d'Ivoire." Land Economics 82(3):404-23.

Conning, J.H., and J.A. Robinson. 2007. "Property Rights and the Political Organization of Agriculture." Journal of Development Economics 82(2):416-47.

Dabrundashvili, T. 2006. "Rights Registration System Reform in Georgia." Paper presented at the Expert Meeting on Good Governance in Land Tenure and Administration. Rome: FAO.

Datta, N. 2006. "Joint Titling: A Win-Win Policy? Gender and Property Rights in Urban Informal Settlements in Chandigarh, India." Feminist Economics 12(1-2):271-98.

Deininger, K. 2003. Land Policies for Growth and Poverty Reduction. A World Bank Policy Research Report. Oxford and New York: World Bank and Oxford University Press. 
Deininger, K., and D.A. Ali. 2008. "Do Overlapping Property Rights Reduce Agricultural Investment? Evidence from Uganda." American Journal of Agricultural Economics 90(4):869-84.

Deininger, K., and R. Castagnini. 2006. "Incidence and Impact of Land Conflict in Uganda." Journal of Economic Behavior \& Organization 60(3): 321-45.

Deininger, K., and J.S. Chamorro. 2004. "Investment and Income Effects of Land Regularization: The Case of Nicaragua." Agricultural Economics 30(2):101-16.

Deininger, K., and S. Jin. 2006. "Tenure Security and Land-Related Investment: Evidence from Ethiopia." European Economic Review 50(5):1245-77.

. 2008. "Land Sales and Rental Markets in Transition: Evidence from Rural Vietnam." Oxford Bulletin of Economics and Statistics 70(1):67-101.

2009. "Securing Property Rights in Transition: Lessons from Implementation of China's Rural Land Contracting Law.” Journal of Economic Behavior \& Organization 70(1-2):22-38.

Deininger, K., D.A. Ali, and T. Alemu. 2008. "Impacts of Land Certification on Tenure Security, Investment, and Land Market Activity: Evidence from Ethiopia.” World Bank Policy Research Working Paper. World Bank, Washington, DC.

Deininger, K., D. Ayalew, and T. Yamano. 2008. "Legal Knowledge and Economic Development: The Case of Land Rights in Uganda." Land Economics 84(4):593-619.

Deininger, K., S. Jin, and H.K. Nagarajan. 2006. "Gender Discrimination and the Returns to Self Employment: Evidence from Rural India.” World Bank Policy Research Working Paper. World Bank, Washington, DC.

Deininger, K., E. Zegarra, and I. Lavadenz. 2003. "Determinants and Impacts of Rural Land Market Activity: Evidence from Nicaragua." World Development 31(8):1385-404.

Deininger, K., D. Ayalew, S. Holden, and J. Zevenbergen. 2008. "Rural Land Certification in Ethiopia: Process, Initial Impact, and Implications for other African Countries." World Development 36(10): $1786-812$.

De Meza, D., and J. Gould. 1992. "The Social Efficiency of Private Decisions to Enforce Property Rights." Journal of Political Economy 100(3):561-80.

Di Tella, R., S. Galiani, and E. Schargrodsky. 2007. "The Formation of Beliefs: Evidence from the Allocation of Land Titles to Squatters." Quarterly Journal of Economics 122(1):209-41.

Do, Q.T., and L. Iyer. 2008. "Land Titling and Rural Transition in Vietnam.” Economic Development and Cultural Change 56(3):531-79.

Dower, P., and E. Potamites. 2005. "Signaling Credit-Worthiness: Land Titles, Banking Practices and Access to Formal Credit in Indonesia." Paper presented at the American Agricultural Economics Association 2005 Annual Meeting, July 24-27, Providence, RI.

Durand-Lasserve, A., and L. Royston. 2002. Holding their Ground: Secure Land Tenure for the Urban Poor in Developing Countries. London: Earthscan Publications.

Easterly, W. 2008. “Institutions: Top Down or Bottom Up?” American Economic Review, Papers and Proceedings 98(2):95-9.

Feder, G., and D. Feeny. 1991. "Land Tenure and Property Rights: Theory and Implications for Development Policy." World Bank Economic Review 5(1):135-53.

Feder, G., and A. Nishio. 1999. "The Benefits of Land Registration and Titling: Economic and Social Perspectives." Land Use Policy 15(1):143-69.

Feder, G., Y. Chalamwong, T. Onchan, and C. Hongladarom 1988. Land Policies and Farm Productivity in Thailand. Baltimore: Johns Hopkins University Press. 
Field, A.J., E. Field, and M. Torero. 2006. "Property Rights and Crop Choice in Rural Peru, 19942004.” MTID Discussion Paper 100. Washington, DC: International Food Policy Research Institute.

Field, E. 2003. Fertility Responses to Land Titling: The Roles of Ownership Security and the Distribution of Household Assets. Cambridge, MA: Harvard University.

2005. "Property Rights and Investment in Urban Slums." Journal of the European Economic Association 3(2-3):279-90.

2007. "Entitled to Work: Urban Property Rights and Labor Supply in Peru." Quarterly Journal of Economics 122(4):1561-602.

Field, E., and M. Torero. 2006. Do Property Titles Increase Credit Access Among the Urban Poor? Evidence from a Nationwide Titling Program. Mimeo, Harvard University.

Firmin-Sellers, K. 2000. "Custom, Capitalism, and the State: The Origins of Insecure Land Tenure in West Africa." Journal of Institutional and Theoretical Economics 156(3):513-30.

Fitzpatrick, D. 2005. “'Best Practice' Options for the Recognition of Customary Tenure.” Development and Change 36(3):449-75.

Fort, R. 2007. Property Rights after Market Liberalization Reforms: Land Titling and Investments in Rural Peru. Wageningen, The Netherlands: Wageningen Academic.

Fred-Mensah, B. 1999. "Capturing Ambiguities: Communal Conflict Management Alternative in Ghana." World Development 27(6):951-65.

Friedman, J., E. Jimenez, and S.K. Mayo. 1988. "The Demand for Tenure Security in Developing Countries." Journal of Development Economics 29(2):185-98.

Galiani, S., and E. Schargrodsky. 2004. "Effects of Land Titling on Child Health." Economics and Human Biology 2(3):353-72.

2005. "Property Rights for the Poor: Effects of Land Titling." Documento de Trabajo 06/ 2005. Buenos Aires: Universidad Torcuato Di Tella, Centro de Investigacion en Finanzas.

Goldstein, M., and C. Udry. 2006. "The Profits of Power: Land Rights and Agricultural Investment in Ghana.” Economic Growth Center Working Paper 929. New Haven, CT: Yale University.

Gordillo, G., A. de Janvry, and E. Sadoulet. 1998. "Between Political Control and Efficiency Gains: The Evolution of Agrarian Property Rights in Mexico." CEPAL Review 66:151-69.

Gould, K. 2006. "Land Regularization on Agricultural Frontiers: The Case of Northwestern Peten, Guatemala." Land Use Policy 23(2):395-407.

Government of Kenya. 2004. Report of the Commission of Inquiry into the Illegal/Irregular Allocation of Public Land. Nairobi: Government Printer.

Government of Mexico. 2000. "Marco legal agrario." Edicion commemorativa - reforma agraria 1915-2000. Mexico, DF: Procuraduria Agraria.

Greif, A. 1993. "Contract Enforceability and Economic Institutions in Early Trade: The Maghribi Traders' Coalition." American Economic Review 83(3):525-48.

Griffith-Charles, C. 2004. "The Impact of Land Titling on Land Transaction Activity and Registration System Sustainability: A Case Study of St. Lucia.” PhD Dissertation. Gainesville, FL: University of Florida.

Gulyani, S., and D. Talukdar. 2008. "Slum Real Estate: The Low-quality High Price Puzzle in Nairobi's Slum Rental Market and its Implications for Theory and Practice." World Development 36(10):1916-37.

Henrysson, E., and S.E. Joireman. 2007. "On the Edge of the Law: The Cost of Informal Property Rights Adjudication in Kisii, Kenya." Working Paper. Wheaton, IL: Wheaton College. 
Holden, S., and H. Yohannes. 2002. "Land Redistribution, Tenure Insecurity, and Intensity of Production: A Study of Farm Households in Southern Ethiopia." Land Economics 78(4):573-90.

Holden, S., K. Deininger, and H. Ghebru. 2008. "Low-cost Land Certification and Land Rental Market Participation in Tigray, Ethiopia." Working Paper. Aas, Norway: Norwegian University of Life Sciences.

Hunt, D. 2004. "Unintended Consequences of Land Rights Reform: The Case of the 1998 Uganda Land Act." Development Policy Review 22(2):173-91.

Jacoby, H., and B. Minten. 2007. "Is Land Titling in Sub-Saharan Africa Cost Effective? Evidence from Madagascar.” World Bank Economic Review 21(3):461-85.

Jacoby, H., G. Li, and S. Rozelle. 2002. "Hazards of Expropriation: Tenure Insecurity and Investment in Rural China." American Economic Review 92(5):1420-47.

Jansen, K., and E. Roquas. 1998. "Modernizing Insecurity: The Land Titling Project in Honduras." Development and Change 29(1):81-106.

Joireman, S.F. 2008. "The Mystery of Capital Formation in Sub-Saharan Africa: Women, Property Rights and Customary Law." World Development 36(7):1233-46.

Kaganova, O., and J. McKelar. 2006. Managing Government Property Assets: International Experiences. Washington, DC: Urban Institute.

Kazianga, H., and W.A. Masters. 2006. "Property Rights, Production Technology, and Deforestation: Cocoa in Cameroon." Agricultural Economics 35(1):19-26.

Kung, J.K.-S. 2002. "Off-Farm Labor Markets and the Emergence of Land Rental Markets in Rural China." Journal of Comparative Economics 30(2):395-414.

Lanjouw, J.O., and P.I. Levy. 2002. "Untitled: A Study of Formal and Informal Property Rights in Urban Ecuador.” Economic Journal 112(482):986-1019.

Lavigne-Delville, P. 2000. "Harmonising Formal Law and Customary Land Rights in FrenchSpeaking West Africa." In C. Toulmin, and J. Quan eds., Evolving Land Rights, Policy and Tenure in Africa. London: DFID/IIED/NRI.

Lavigne-Delville, P., C. Toulmin, J.-P. Colin, and J.-P. Chauveau 2002. Negotiating Access to Land in West Africa: A Synthesis of Findings from Research on Derived Rights to Land. London: IIED/GRET.

Leuprecht, P. 2004. "Land Concessions for Economic Purposes in Cambodia: A Human Rights Perspective." Report by the Special Representative of the Secretary General for human rights in Cambodia. Phnom Penh: United Nations, Cambodia Office of the High Commissioner for Human Rights.

Lobo, A., and S. Balakrishnan. 2002. "Report Card on Service of Bhoomi Kiosks: An Assessment of Benefits by Users of the Computerized Land Records System in Karnataka." Working Paper. Bangalore: Public Affairs Centre.

Lueck, D., and T. Miceli. 2006. "Property Law." Arizona Legal Studies, Discussion Paper 06-19. Tucson, AZ: University of Arizona.

Mabogunje, A.L. 1992. "Perspective on Urban Land and Urban Management Policies in SubSaharan Africa." World Bank Technical Paper 196, Washington, DC: Africa Technical Department Series.

Macours, K., A. de Janvry, and E. Sadoulet. 2004. "Insecurity of Property Rights and Matching in the Tenancy Market.” Working Paper 992. Berkeley: Department of Agricultural \& Resource Economics, UC Berkeley.

Malik, A., and R. Schwab. 1991. "Optimal Investments to Establish Property Rights in Land." Journal of Urban Economics 29(295):309. 
Maurer, N., and L. Iyer. 2008. "The Cost of Property Rights: Establishing Institutions on the Philippine Frontier under American Rule, 1898-1918.” Working Paper 14298. Cambridge, MA: National Bureau of Economic Research.

Meinzen-Dick, R., and E. Mwangi. 2009. "Cutting the Web of Interests: Pitfalls of Formalizing Property Rights." Land Use Policy 26(1):36-43.

Mushinski, D.W. 1999. "An Analysis of Offer Functions of Banks and Credit Unions in Guatemala." Journal of Development Studies 36(2):88-112.

Nettle, K. 2006. “Titles vs Deeds: International Experience and Implications for India.” Paper presented at the MoRD/World Bank workshop on "Land Policies for Accelerated Growth and Poverty Reduction in India", January 5 and 6, New Delhi.

North, D.C. 1971. Structure and Change in Economic History. New York: W.W. Norton.

Panda, P., and B. Agarwal. 2005. "Marital Violence, Human Development and Women's Property Status in India." World Development 33(5):823-50.

Pande, R., and C. Udry. 2005. "Institutions and Development: A View from Below." Working Papers 928. New Haven, CT: Yale University, Economic Growth Center.

Payne, G., A. Durand-Lasserve, and C. Rakodi. 2008. Social and Economic Impacts of Land Titling Programmes in Urban and Peri-urban Areas: International Experience and Case Studies of Senegal and South Africa. Oslo and Stockholm: SIDA and Norwegian Ministry of Foreign Affairs.

Peters, P. 2004. "Inequality and Social Conflict Over Land in Africa." Journal of Agrarian Change $4(3): 269-314$.

PLAAS (Programme for Land and Agrarian Studies) and NLC (National Land Committee). 2003. "Submission to the Portfolio Committee for Land and Agriculture: The Communal Land Rights Bill." (http://www.plaas.org.za/policy-engagement/communal-land-rights-bill-clrb)

Powelson, J.P. 1988. The Story of Land: A World History of Land Tenure and Agrarian Reform. Cambridge, MA: The Lincoln Institute of Land Policy.

Quisumbing, A.R., and J.A. Maluccio. 2003. "Resources at Marriage and Intrahousehold Allocation: Evidence from Bangladesh, Ethiopia, Indonesia, and South Africa." Oxford Bulletin of Economics and Statistics 65(3):283-327.

Ravallion, M., and D. van de Walle. 2008. "Does Rising Landlessness Signal Success or Failure for Vietnam's Agrarian Transition?" Journal of Development Economics 87(2):191-209.

Rozelle, S., and J.F.M. Swinnen. 2004. "Success and Failure of Reform: Insights from the Transition of Agriculture." Journal of Economic Literature 42(2):404-56.

Schweigert, T.E. 2007. "Land Title, Tenure Security, Investment and Farm Output: Evidence from Guatemala." Journal of Developing Areas 40(1):115-26.

Shavell, S. 2003. "Economic Analysis of Property Law." NBER Working Paper 9695. National Bureau of Economic Research, Inc.

Siamwalla, A. 1990. "The Thai Rural Credit System: Public Subsidies, Private Information, and Segmented Markets.” World Bank Economic Review 4(3):271-95.

Sjaastad, E., and D. Bromley. 2000. "The Prejudices of Property Rights: On Individualism, Specificity, and Security in Property Regimes.” Development Policy Review 18(4):365-89.

1997. "Indigenous Land Rights in Sub-Saharan Africa: Appropriation, Security and Investment Demand." World Development 25(4):549-62.

de Soto, H. 2000. The Mystery of Capital: Why Capitalism Triumphs in the West and Fails Everywhere else. New York: Basic Books.

Stern, N. 2008. "The Economics of Climate Change." American Economic Review, Papers and Proceedings 98(2):1-37. 
Stiglitz, J.E., and A. Weiss. 1981. "Credit Rationing in Markets with Imperfect Information." American Economic Review 71(3):393-410.

Transparency International India. 2005. India Corruption Study 2005. New Delhi: Transparency International.

Udry, C. 1996. "Gender, Agricultural Production, and the Theory of the Household." Journal of Political Economy 104(5):1010-46.

UNECE. 1996. "Land Administration Guidelines, With Special References to Countries in Transition." United Nations Economic Commission for Europe, ECE/HBP/96, New York and Geneva.

Vogl, T.S. 2007. "Urban Land Rights and Child Nutritional Status in Peru, 2004." Economics and Human Biology 5(2):302-21.

World Bank. 2002. Mexico Land Policy: A Decade after the Ejido Reforms. Washington, DC: The World Bank, Rural Development and Natural Resources Sector Unit. 2003. "Nicaragua Land Policy and Administration: Towards a More Secure Property Rights Regime.” Report 26683-NI. World Bank, Washington, DC.

2007. Doing Business 2008. Washington DC: World Bank, International Finance Corporation, and Oxford University Press.

Yang, D.T. 1997. "China's Land Arrangements and Rural Labor Mobility.” China Economic Review $8(2): 101-15$.

Zepeda, G. 2000. Transformación Agraria. Los Derechos de Propriedad en el Campo Mexicano bajo el Nuevo Marco Institucional. Mexico: CIOAC. 